\title{
Is microbial reduction of Fe (III) in podzolic soils influencing C release?
}

\author{
Marie-Liesse Vermeire ${ }^{\mathrm{a}, \mathrm{b}, *}$, Steeve Bonneville ${ }^{\mathrm{c}}$, Benoit Stenuit ${ }^{\mathrm{d}, \mathrm{e}}$, Bruno Delvaux ${ }^{\mathrm{a}}$, \\ Jean-Thomas Cornélis ${ }^{\mathrm{a}, \mathrm{f}}$ \\ ${ }^{a}$ Soil Science and Environment Geochemistry, Earth \& Life Institute, Université catholique de Louvain (UCL), Croix du Sud 2, 1348 Louvain-la-Neuve, Belgium \\ ${ }^{\mathrm{b}}$ Department of Biological Sciences, Faculty of Sciences, University of Cape Town (UCT), Private Bag X3, Rondebosch, 7701 Cape Town, South Africa \\ ${ }^{\mathrm{c}}$ Biogéochimie et Modélisation du système Terre, Département Géosciences, Environnement et Société (DGES), Université Libre de Bruxelles (ULB), 50 av. F. D. Roosevelt, \\ 1050 Brussels, Belgium \\ ${ }^{\mathrm{d}}$ Applied Microbiology Laboratory, Earth \& Life Institute, Université catholique de Louvain (UCL), Croix du Sud 2, bte. L07.05.19, B-1348 Louvain-la-Neuve, Belgium \\ ${ }^{\mathrm{e}}$ Polytech Montpellier, University of Montpellier, Joint Research Unit of Agropolymer Engineering and Emerging Technologies (IATE, UMR 1208), Montpellier, France \\ ${ }^{\mathrm{f}}$ Water-Soil-Plant Exchanges, TERRA Teaching and Research Centre, Gembloux Agro-Bio Tech, University of Liège (ULG), Passage des Déportés 2, 5030 Gembloux, \\ Belgium
}

\section{A R T I C L E I N F O}

Handling Editor: Michael Vepraskas

Keywords:

Organo-mineral associations

Dissimilatory iron reduction (DIR)

Shewanella putrefaciens

Fe oxides

Natural organic matter

Podzol

Soil

\begin{abstract}
A B S T R A C T
Fe(III) oxides stabilize soil organic matter by forming Fe organo-mineral associations (Fe-OMA). Under anoxic conditions, Fe-OMA may be destabilized by microbial dissimilatory iron reduction that releases aqueous Fe(II) and also possibly adsorbed or co-precipitated organic matter. Soil spodic horizons that accumulate Fe-OMA are ideal natural materials to study such impact. Here, we study three spodic horizons from pedons (P) of increasing age: P-270 yrs, P-330 yrs and P-530 yrs. Their contents of total carbon and short range ordered (SRO) Fe oxides increase with soil age from, respectively, 1486 to 3618 and 13 to $249 \mu \mathrm{mol} \mathrm{g}^{-1}$. The samples were incubated for $96 \mathrm{~h}$ under anoxic conditions, with and without Shewanella putrefaciens (a model dissimilatory Fe(III)-reducing bacteria) in a minimal medium devoid of any $\mathrm{pH}$ buffer and external electron donor. The concentration of dissolved Fe(II), total Fe and organic C was monitored at 9 time steps. With increasing age, both the rate and extent of microbial Fe(III) reduction increased after $S$. putrefaciens addition. In P-270 yrs, P-330 yrs and P-

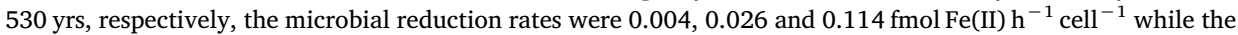
amounts of released Fe(II) were $0.23,0.32$ and $1.98 \mu \mathrm{mol} \mathrm{Fe}(\mathrm{II}) \mathrm{g}^{-1}$, both being strongly correlated with SRO Fe oxides content. Dissolved organic carbon (DOC) was released with or without $S$. putrefaciens in all samples (up to $73 \mu \mathrm{mol} \mathrm{OC}^{-1}$ after $96 \mathrm{~h}$ in P-530 yrs). Adding $S$. putrefaciens significantly increased DOC release, but only in P270 yrs. Podzol development thus increases the impact of anoxia on Fe(II) release since organic matter accumulation impedes Fe oxide crystallization, thereby amplifying Fe availability for Fe reducing microbes. The evolution of Fe oxide content and crystallinity thus affects the fate of both $\mathrm{C}$ and $\mathrm{Fe}$ in soils.
\end{abstract}

\section{Introduction}

Organo-mineral associations involving Fe oxides (Fe-OMA) stabilize soil organic matter (OM) (Kleber et al., 2015; Kögel-Knabner et al., 2008; Baldock and Skjemstad, 2000). Fe-OMA result from either coprecipitation (Mikutta et al., 2008) or adsorption of OM to Fe oxide surfaces (Eusterhues et al., 2014). When anoxia sets in, Fe reducing bacteria use mineral $\mathrm{Fe}(\mathrm{III})$ as electron acceptors for OM oxidation. Although Fe(III) reduction can be abiotic (Melton et al., 2014), microbial Fe(III) reduction is one of the most significant biogeochemical process in soils (Weber et al., 2006; Lovley, 2013; Kappler and Straub,
2005; Nealson and Myers, 1992). This process releases aqueous Fe(II) and can destabilize Fe-OMA. Soil OM dissolution under anoxic conditions is currently under debate. Some studies show that dissolved organic carbon (DOC) release is linked to reductive conditions (Grybos et al., 2009; Hagedorn et al., 2000; Buettner et al., 2014; Kalbitz et al., 2000; Knorr, 2013) while other ones report no evidence of DOC production during anoxic episodes (Moore and Dalva, 2001; Fiedler and Kalbitz, 2003; Henneberry et al., 2012). Several hypotheses were proposed to explain the interplay between microbial Fe(III) reduction and DOC release. First, the pH increase following Fe(III) reduction - a $\mathrm{H}^{+}$consuming process - has been related to OM dissolution (Buettner et al.,

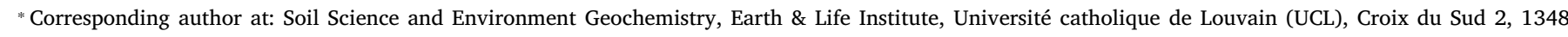
Louvain-la-Neuve, Belgium.

E-mail addresses: Marie-liesse.vermeire@uct.ac.za (M.-L. Vermeire), steeve.bonneville@ulb.ac.be (S. Bonneville), benoit.stenuit@uclouvain.be (B. Stenuit), bruno.delvaux@uclouvain.be (B. Delvaux), jtcornelis@ulg.ac.be (J.-T. Cornélis). 
2014; Grybos et al., 2009; Grybos et al., 2007). The pH rise decreases the amplitude of positive charge born by $\mathrm{Fe}(\mathrm{III})$ oxides whereas it increases the negative charge of OM (Avena and Koopal, 1999), thereby reducing Fe-OMA stability by electrostatic repulsion. Second, DOC fate in anoxia is governed by bacteria independently of microbial Fe(III) reduction through the following processes: (i) the production of soluble organic metabolites, prior to fermentation (Kalbitz et al., 2000); (ii) DOC release through OM degradation via hydrolysis and fermentation (Moore and Dalva, 2001; Röling et al., 2007); (iii) progressive DOC accumulation resulting from slow decomposition in anoxia (Keiluweit et al., 2016; Fiedler and Kalbitz, 2003; Kögel-Knabner et al., 2010). Third, the reductive dissolution of Fe(III) oxides induces the desorption of sorbed OM (Hedges and Keil, 1995; Adhikari et al., 2016; KögelKnabner et al., 2010), or the release of OM entrapped in Fe-cemented aggregates (Henderson et al., 2012; Buettner et al., 2014).

In the literature, no clear picture has yet emerged regarding the impact of adsorbed and co-precipitated OM on the microbial reactivity of Fe phases. Previous studies (Pédrot et al., 2011; Shimizu et al., 2013; Eusterhues et al., 2014; Poggenburg et al., 2016; Adhikari et al., 2017; Cooper et al., 2017; Poggenburg et al., 2018) focused on fresh and synthetic OMA, but not on those formed in soils. Actually, fresh synthetic OMA considerably differ from natural soil OMA as they did not form from complex soil solutions and/or evolve from long-term transformations (Cornell and Schwertmann, 2003). So far, studies on fresh, synthetic OMA revealed that the Fe(III) reduction dynamics and longterm stability of OMA in soils might be related to (i) their C:Fe ratio, (ii) the composition of the associated OM, (iii) the metabolism of DIR microorganisms (electron transfer mechanisms). Shewanella spp. can use various strategies to reduce Fe(III) from oxides - i.e. direct contact, electron shuttles, or by production of complexing ligands like siderophores (Cooper et al., 2017) - while Geobacter sp. does not produce electron-shuttling molecules or chelators relying mostly on direct contact (Nevin and Lovley, 2000). Accordingly, faster Fe(III) reduction rates were measured with increasing $\mathrm{C}$ load in fresh $\mathrm{Fe}-\mathrm{OM}$ associations in studies using Shewanella spp. (Pédrot et al., 2011; Shimizu et al., 2013; Cooper et al., 2017; Adhikari et al., 2017), while an inhibition of the reduction of SRO-Fe oxide was observed with increasing adsorption or coprecipitation involving OC when Geobacter spp. is used (Eusterhues et al., 2014; Poggenburg et al., 2016). According to Cooper et al. (2017), electron-shuttling is the dominant mechanism of microbial Fe(III) reduction in OM-rich environments, such as soils, sediments, and peat, where natural OM is the most likely to interact with $\mathrm{Fe}(\mathrm{III})$ oxide during and also after mineral formation.

Podzols have received a lot of attention regarding soil OM dynamics and stabilization by mineral phases (Schulze et al., 2009; Schmidt et al., 2000; Grand and Lavkulich, 2013; Jones et al., 2015) since spodic horizons usually accumulate Fe-OMA. The processes governing the accumulation and dissolution of Fe and OM in the illuvial spodic horizon are still debated. Few studies considered the influence of redox oscillations on Fe and OC dynamics in podzols (Sauer et al., 2007) even though reductive processes occur in podzols (Vodyanitskii et al., 2006; Kanev, 2011). Anoxic episodes can result from pore clogging by OMA that impedes water infiltration and forms perched water table during rainy periods (Fritsch et al., 2011; Do Nascimento et al., 2004; Montes et al., 2011; Buurman and Jongmans, 2005). The occurrence of redox cycles in clogged illuvial B horizons make the spodic horizon relevant to study the impact of dissimilatory iron reduction (DIR) on the stability of Fe-OMA.

Here, we study the impact of microbial DIR on the release of Fe(II), total Fe and DOC. We use soil samples from spodic horizons of increasing age and increasing Fe-OMA contents. We use the facultative anaerobic Fe-reducing bacteria Shewanella putrefaciens for its metabolic versatility, which makes it an appropriate model for environments with fluctuating natural conditions (Glasauer et al., 2003; Nealson and Saffarini, 1994; Hau and Gralnick, 2007). We test the hypothesis that (1) Fe(III) dissolution, induced by DIR bacteria, results in a release of DOC, previously adsorbed or co-precipitated; and (2) DOC release increases with increasing amounts of SRO-Fe oxide and mineral-protected $\mathrm{OC}$, and thus with increasing soil age in the chronosequence.

\section{Materials and methods}

\subsection{Soil samples}

Soil samples were collected from a podzolic chronosequence under a Sitka spruce (Picea sitchensis) forest, located near Cox Bay, west coast of Vancouver Island, British Columbia (latitude $49^{\circ} 6^{\prime} \mathrm{N}$, longitude $125^{\circ}$ $52^{\prime} \mathrm{W}$ ) (Cornelis et al., 2014; Vermeire et al., 2016). The soils have developed from sandy beach deposits, which are emerging at a rate of $0.26 \mathrm{~m}$ per year (Singleton and Lavkulich, 1987). The ages of the deposits were determined by dendrochronology and geomorphology and range from 0 to 530 yrs (Vermeire et al., 2016). A progressive deepening and differentiation of genetic horizons is observed as podzolization proceeds (Cornelis et al., 2014). The soil samples used for our incubations were collected from the three oldest pedons (P), i.e. 270, 330 and 530 years old, in the P-270 yrs Bh horizon and P-330 yrs and P$530 \mathrm{yrs}$ Bhs horizons. The materials contain large amounts of quartz. Minor minerals are sodic feldspars, amphibole (hornblende), pyroxene (augite), kaolinite, micas (illite) and chlorite (Vermeire et al., 2016). In the field, we observed a cementation/induration of the spodic illuvial B horizons, particularly in P-330 and P-530 yrs Bhs, linked to the accumulation of $\mathrm{Fe}$ and OM. Because of the high mean annual precipitation $(\sim 3200 \mathrm{~mm})$, episodic waterlogging alternating with phases of desiccation occurs particularly in P-330 and P-530 yrs Bhs, as revealed by the observed monomorphic micromorphology of OM coatings, presenting desiccation cracks (Vermeire et al., 2018).

The soil samples were air-dried and sieved to a size $<2 \mathrm{~mm}$ according to NF ISO 11464 (AFNOR, 2006) before analysis. Major soil characteristics (Table 1) were measured as described by Vermeire et al. (2016). Briefly, soil pH was measured in $5 \mathrm{~g}: 25 \mathrm{~mL}$ soil:water suspension (Page et al., 1982). Cation exchange capacity (CEC) and the content of exchangeable cations were determined, according to Page et al. (1982), in ammonium acetate $1 \mathrm{M}$ at pH 7 and measured by ICP-AES. Soil particle-size analysis was achieved by quantitative recovery of clay $(<2 \mu \mathrm{m})$, silt $(2-50 \mu \mathrm{m})$ and sand $(>50 \mu \mathrm{m})$ fractions after sonication and dispersion with $\mathrm{Na}^{+}$-saturated resins without any previous $\mathrm{H}_{2} \mathrm{O}_{2}$ oxidation of OM (Rouiller et al., 1972).

Table 1

Major soil characteristics: $\mathrm{pH}$ in water, cationic exchange capacity (CEC), exchangeable cations, base saturation (\%BS), particle-size distribution.

\begin{tabular}{|c|c|c|c|c|c|c|c|c|c|c|c|c|}
\hline Profile & Horizon & $\frac{\text { Depth }}{\mathrm{cm}}$ & $\frac{\mathrm{pH}}{\text { (water) }}$ & $\begin{array}{l}\mathrm{CEC} \\
\mathrm{cmol}_{\mathrm{c}} \mathrm{kg}^{-1}\end{array}$ & \multicolumn{4}{|c|}{ Exchangeable cations $\left(\mathrm{cmol}_{\mathrm{c}} \mathrm{kg}^{-1}\right)$} & $\% \mathrm{BS}$ & \multicolumn{3}{|c|}{ Particle size distribution (\%) } \\
\hline P-270 yrs & $\mathrm{Bh}$ & $7-23$ & 5.1 & 5.94 & 0.59 & 0.04 & 0.41 & 0.13 & 19.76 & 97.2 & 1.7 & 1.1 \\
\hline P-530 yrs & Bhs & $9.5-10$ & 4.5 & 23.35 & 0.24 & 0.08 & 0.13 & 0.07 & 2.23 & $\mathrm{nd}^{\mathrm{a}}$ & nd & no \\
\hline
\end{tabular}

${ }^{\mathrm{a}}$ nd: not determined. 


\subsection{Chemical extractions: $F e$ and $C$ pools in soil samples}

The different Fe pools in the soil samples were extracted separately with (i) sodium pyrophosphate $-0.1 \mathrm{M}$ at $\mathrm{pH} 10$ for $16 \mathrm{~h}$ (Bascomb, 1968) -, (ii) ammonium oxalate-oxalic acid $-0.2 \mathrm{M}$ at $\mathrm{pH} 3$ for $4 \mathrm{~h}$ in darkness (Blakemore et al., 1987) - and (iii) dithionite-citrate-bicarbonate (DCB) $-75^{\circ} \mathrm{C}$, pH 8 (Mehra and Jackson, 1960) -, and quantified by ICP-AES (Thermo Scientific, iCAP 6000). Pyrophosphate (p) is considered to extract Fe bound to organic matter ("Fe-OM"). Yet its dispersing action may include $\mathrm{Fe}$ oxide nanoparticles in $\mathrm{Fe}_{\mathrm{p}}$ even after centrifugation (i.e., $4250 \times g$ for $20 \mathrm{~min}$ ) (Jeanroy and Guillet, 1981). Dark oxalate (o) is considered to extract organo-Fe complexes and SRO Fe-oxides (ferrihydrite and eventually goethite or lepidocrocite: "SRO-Fe") (Poulton and Canfield, 2005). DCB is considered to dissolve "free $\mathrm{Fe}$ " $\left(\mathrm{Fe}_{\mathrm{d}}\right)$, that includes all $\mathrm{Fe}$ forms, except silicate: $\mathrm{Fe}$ OM, SRO-Fe and crystalline Fe oxide (goethite and hematite): "Cry-Fe". The amounts of Fe phases (in $\mu \mathrm{mol} \mathrm{Fe}^{-1}$ soil) are calculated as follows:

$$
\begin{aligned}
& \text { - Fe-OM }=\mathrm{Fe}_{\mathrm{p}} \\
& \text { - } \mathrm{SRO}-\mathrm{Fe}=\mathrm{Fe}_{\mathrm{o}}-\mathrm{Fe}_{\mathrm{p}} \\
& \text { - Cry-Fe }=\mathrm{Fe}_{\mathrm{d}}-\mathrm{Fe}_{\mathrm{o}} .
\end{aligned}
$$

The different soil organic carbon (OC) fractions were estimated following the protocol of Mikutta et al. (2006). Three fractions were distinguished: (i) "oxidizable", (ii) "mineral-protected" and (iii) "recalcitrant" OC. They refer to three operationally-defined OC fractions, respectively: (i) oxidized by sodium hypochlorite ( $\mathrm{NaOCl}$ ), (ii) released by hydrofluoric acid (HF), (iii) resistant to previous oxidation and HF treatments (Kleber et al., 2005; Mikutta et al., 2006; Siregar et al., 2005; Torn et al., 2009; Von Lützow et al., 2007). Briefly, $3 \mathrm{~g}$ of airdried soil sample were reacted three times with $30 \mathrm{~mL}$ of $6 \mathrm{wt} \% \mathrm{NaOCl}$ adjusted to $\mathrm{pH} 8.0$ for $6 \mathrm{~h}$ at $25^{\circ} \mathrm{C}$. Samples were subsequently washed twice with $30 \mathrm{~mL} 1 \mathrm{M} \mathrm{NaCl}$ and then with deionized water. $2.25 \mathrm{~g}$ of each $\mathrm{NaOCl}$-treated sample were exposed four times consecutively to $15 \mathrm{~mL} 10 \% \mathrm{HF}$ for $2 \mathrm{~h}$ in order to dissolve minerals and to release associated OC, and then washed five times with $15 \mathrm{~mL}$ deionized water. The amount of stable carbon (composed of the mineral-protected and recalcitrant OC) was quantified as the amount of carbon left after oxidation with $\mathrm{NaOCl}$ (Kleber et al., 2005). The oxidizable OC was calculated by subtracting the stable OC fraction from the total OC content. The NaOCl-treated samples were then exposed to HF treatment in order to dissolve minerals and associated OC. The remaining OC after HF extraction was defined as 'recalcitrant' OC. The HF-extractable OC, i.e. mineral-protected $\mathrm{OC}$, was calculated by subtracting the recalcitrant $\mathrm{OC}$ fraction from the stable OC fraction. The OC content in the solid fractions was measured with a FLASH 2000 Analyzer (ThermoFisher Scientific). In summary, the OC fractions (in $\mu \mathrm{mol} \mathrm{Cg}^{-1}$ soil) are calculated as follow:

\section{- Oxidizable OC $=$ Total OC - Stable OC \\ - Mineral-Protected OC $=$ Stable OC - Recalcitrant OC.}

The soil samples were not sterilized since autoclaving likely modifies Fe minerals and thus possibly OMA.

\subsection{Microbial incubations}

Shewanella putrefaciens strain LMG 2279, a model microorganism for DIR (MacDonell and Colwell, 1985), was provided by the Belgian Coordinated Collection of Microorganism (BCCM, Brussels, Belgium). It was routinely grown under aerobic conditions at $25^{\circ} \mathrm{C}$ on agar LuriaBertani (LB) plates and in liquid LB medium on a rotary shaker set at $120 \mathrm{rpm}$. A single colony was used to inoculate precultures grown aerobically to the late exponential phase $(\sim 24 \mathrm{~h})$ in $250 \mathrm{~mL}$ Erlenmeyer containing $50 \mathrm{~mL} \mathrm{LB}$ medium. Precultures were used to inoculate at
$0.6 \%(\mathrm{v} / \mathrm{v}) 500 \mathrm{~mL}$ flasks containing $150 \mathrm{~mL} \mathrm{LB}$ medium and the main cultures were grown to the mid-exponential phase $(\sim 12 \mathrm{~h})$. Cultures were harvested by centrifugation at $8500 \mathrm{~g}$ for $15 \mathrm{~min}$ at $4{ }^{\circ} \mathrm{C}$. Cells were then washed three times with a sterile saline solution "S" (composed of $28 \mathrm{mM} \mathrm{NH} 4 \mathrm{Cl}, 1 \mathrm{mM} \mathrm{CaCl} \cdot 2 \mathrm{H}_{2} \mathrm{O}$, at $\mathrm{pH} 7.5$ ) and concentrated cell suspensions were used for further incubations. Cell concentration of strain LMG 2279 cultures was estimated by optical density (OD) measurements at $600 \mathrm{~nm}$ using a conversion factor for Escherichia coli (i.e. one unit of $\mathrm{OD}_{600}$ is equal to $8 \times 10^{8}$ cells $\mathrm{mL}^{-1}$ ) (Agilent). Cell concentration of strain LMG 2279 cultures was also determined by measuring dry weight of cell suspensions taking into account a mass of $7 \times 10^{-13} \mathrm{~g}$ per $S$. putrefaciens cell (Claessens et al., 2006).

All incubations were conducted for $96 \mathrm{~h}$ in $160 \mathrm{~mL}$ sterile serum bottles sealed with airtight butyl rubber stoppers and aluminum crimp caps at $25^{\circ} \mathrm{C}$ in the dark on a rotary shaker $(180 \mathrm{rpm})$. Before starting the inoculation (and sampling at t0), the soil samples $(<2 \mathrm{~mm}$, uncrushed) were resuspended in $120 \mathrm{~mL}$ sterile saline solution "S" and left to equilibrate for $7 \mathrm{~h}$, until $\mathrm{pH}$ equilibrium was reached. The suspensions were not buffered, because phosphate and carbonate can interact with $\mathrm{Fe}$, and form aqueous complexes or ferrous solids (Zachara et al., 2001; Wang et al., 2015) while organic buffers would impede the accurate quantification of dissolved organic carbon (DOC). In addition, soil $\mathrm{pH}$ in the field ranges between pH 4.5 and 5.5 (Table 1), thus, adjusting $\mathrm{pH}$ to neutrality would have altered the natural podzolic conditions. Except for nitrogen ( $28 \mathrm{mM} \mathrm{NH}_{4}{ }^{+}$in saline solution), no other nutrients were added (e.g., no external organic electron donors, phosphate or vitamins). The bottles were purged with sterile $\mathrm{N}_{2}$ for $1 \mathrm{~h}$ to reach anoxic conditions. All experiments were carried out in triplicates.

A first series of experiments was conducted to compare microbial Fe (III) reduction activities of $S$. putrefaciens strain LMG2279 at three different stages of podzolization (P-270 yrs, P-330 yrs and P-530 yrs) and contrasting $\mathrm{Fe}$ and $\mathrm{OM}$ contents. Suspensions of $3 \mathrm{~g}$ of soil samples in $120 \mathrm{~mL}$ sterile saline solution were inoculated with $S$. putrefaciens (B) under anoxic (A) conditions (referred to as "AB" treatments, i.e. P270 yrs $\mathrm{AB}, \mathrm{P}-330$ yrs $\mathrm{AB}$ and $\mathrm{P}-530$ yrs $\mathrm{AB}$ ).

In a second series of experiments, several control incubations were carried out in triplicate: (i) without $S$. putrefaciens to assess the contribution of autochthonous microorganisms (i.e., $3 \mathrm{~g}$ of soil sample suspended in $120 \mathrm{~mL} \mathrm{~S}$ solution under anoxic conditions ' $\mathrm{A}$ ', hereafter referred to as P-270 yrs A, P-330 yrs A and P-530 yrs A); (ii) with $S$. putrefaciens under aerobic conditions $(\mathrm{O})$ to assess the contribution of anoxia to the release of dissolved Fe(II) and DOC ( $3 \mathrm{~g}$ of soil samples in $120 \mathrm{~mL}$ sterile saline solution only for P-530 yrs sample - hereafter referred to as P-530 yrs OB); (iii) control S. putrefaciens incubations in S solution under anoxic conditions to assess the contribution of $S$. putrefaciens to the release of DOC without soil material (hereafter referred to as 'BB').

The initial cell density of each incubation with $S$. putrefaciens ("B" treatments) was adjusted to $3.25 \times 10^{7}$ cells $\mathrm{mL}^{-1}$. Liquid aliquots were retrieved at 9 time steps (t0 to t8), to monitor the concentration of dissolved Fe(II), total dissolved Fe and DOC. At each sampling point, three aliquots of $1 \mathrm{~mL}$ were filtered through $0.2 \mu \mathrm{m}$ pore size PTFE membrane filters. Two aliquots (for total dissolved Fe and dissolved Fe (II) measurements, respectively) were filtered directly into $250 \mu \mathrm{L} \mathrm{HCl}$ $0.5 \mathrm{M}$, while a third aliquot was preserved into a glass vial for DOC measurement. The samples were stored at $4{ }^{\circ} \mathrm{C}$ in the dark for maximum two days until further processing.

Dissolved Fe(II) and total Fe concentrations were measured by spectrophotometry following the ferrozine method (Viollier et al., 2000) using a Genesys 10S VIS spectrophotometer (Thermo Fischer Scientific). DOC concentrations were measured on a Shimadzu TOC-L analyzer (detection limit of $4 \mu \mathrm{g} \mathrm{CL}^{-1}$ or $0.33 \mu \mathrm{mol} \mathrm{CL}{ }^{-1}$ ) and were corrected using ultrapure water blanks (blank level $<0.2 \mathrm{mg} \mathrm{CL}^{-1}$ ). The analytic accuracy was evaluated at $\pm 2.6 \%$, after repeated analyses of freshly prepared standard solutions of potassium hydrogen phthalate 
every 6 to 9 samples. At the end of the experiment ( $96 \mathrm{~h}$ ), the suspensions were filtered through $0.2 \mu \mathrm{m}$ pore size PTFE membrane filters. The membrane filters were further processed for scanning electron microscopy (SEM) as described in the Section 2.4. The pH was measured and the total concentrations of $\mathrm{Al}, \mathrm{Fe}, \mathrm{K}, \mathrm{Mg}, \mathrm{Mn}, \mathrm{P}$ and $\mathrm{S}$ were determined in the filtrates by ICP-AES (Thermo Fischer Scientific, iCAP 6000). We utilized Microsoft Excel for statistical analysis (Linear regressions and $t$-tests). In addition, a linear mixed effects model was performed in R 3.5.1 (R Development Core Team, 2017) to test the differences between the DOC release in the control treatment (A) and treatment with bacteria (AB). The fixed factors were soil and bacteria, and the random factor was time. The model was performed using 'lme4' 1.1-13 (Bates et al., 2015). An ANOVA of the linear mixed effects model was further run to determine the significance of the main effects and/or interaction using 'car' 2.1-4 (Fox and Weisberg, 2011). The ANOVA used the Kenward-Roger approximation for the degrees of freedom. Before running any analysis, response variables were log transformed to ensure normal distribution. Differences were considered to be significant at $\mathrm{P}<0.05$.

\subsection{Scanning electron microscopy (SEM)}

Samples for SEM were prepared according to Schädler et al. (2008) immediately after the end of incubation $(96 \mathrm{~h})$ in order to avoid artifacts (e.g. cell shrinkage during dehydration, surface alteration or formation of secondary minerals). The PFTE membrane filters were immerged in a $2.5 \%$ glutaraldehyde solution for $1 \mathrm{~h}$ to chemically fix the biological structures, then rinsed three times with a Dulbecco's phosphate buffered solution, and finally rinsed twice with milliQ water. Subsequently the samples were dehydrated by successive resuspensions in isopropanol at $10 \%, 30 \%, 50 \%, 70 \%, 80 \%, 90 \%, 96 \%, 100 \%$, vol/ vol. Imagery was performed with an Ultra55 FEG-SEM (Zeiss), fitted with a secondary electron detector. Morphologic analysis was performed at 3.00 or $5.00 \mathrm{kV}$ accelerating voltage. The elemental analysis was carried out by Energy Dispersive X-ray spectroscopy (EDX) using a silicon drift detector (Quantax system, Bruker) at an acceleration voltage of 3,5 or $15 \mathrm{kV}$.

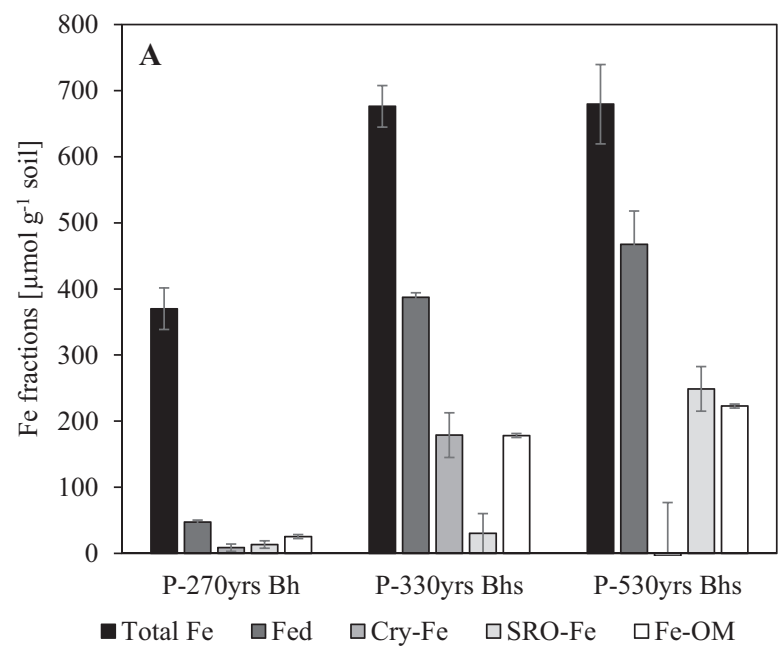

\section{Results and discussion}

\subsection{Characterization of Fe and $\mathrm{C}$ pools}

With increasing age, $\mathrm{OC}$ and free $\mathrm{Fe}\left(\mathrm{Fe}_{\mathrm{d}}\right)$ accumulate in illuvial $\mathrm{B}$ horizons (Fig. 1). Total Fe content $\left(\mu \mathrm{mol} \mathrm{g}^{-1}\right)$ amounts to 370 in P$270 \mathrm{yrs} \mathrm{Bh}$, and 680 in P-330 yrs and P-530 yrs Bhs horizons. Fe $\mathrm{d}_{\mathrm{d}}$ content $\left(\mu \mathrm{mol} \mathrm{g}{ }^{-1}\right)$ largely increases in the order P-270 yrs Bh $(47) \ll \mathrm{P}$ 330 yrs (387) < P-530 yrs (468). SRO-Fe represents $8 \%$ of free Fe in P$330 \mathrm{yrs}$, and $53 \%$ in P-530 yrs. In contrast, crystalline Fe oxide represents $46 \%$ of free $\mathrm{Fe}$ in P-330 yrs but is negligible in P-530 yrs. In both P-330 yrs and P-530 yrs Bhs horizons, about half of free Fe, $46-48 \%$, is extracted by pyrophosphate, and could be considered as bound to $\mathrm{OM}$ either as colloidal $\mathrm{Fe}$ oxide particle or $\mathrm{Fe}$ ion.

With increasing age, OC content $\left(\mu \mathrm{mol} \mathrm{g}^{-1}\right)$ also increases since it amounts to 1487,2088 and 3618 in P-270, P-330 and P-530 yrs, respectively (Fig. 1). The distribution of operationally defined OC fractions differs between soil horizons. In P-270 yrs, NaOCl-oxidizable OC $\left(1166 \mu \mathrm{mol} \mathrm{g}^{-1}\right)$ represents $78 \%$ of total OC while recalcitrant and mineral-protected pools (respectively, 254 and $68 \mu \mathrm{mol} \mathrm{g}^{-1}$ ) account for $17 \%$ and $5 \%$ of total OC. In contrast, mineral-protected OC in P$330 \mathrm{yrs}$ and P-530 yrs reach 1099 and $1324 \mu \mathrm{mol} \mathrm{g}^{-1}$, respectively, representing $52 \%$ and $37 \%$ of total OC. NaOCl-oxidizable OC content in P-530 yrs $\left(1632 \mu \mathrm{mol} \mathrm{g}^{-1}\right.$, representing $45 \%$ of total OC) is twice the one of P-330 yrs $\left(852 \mu \mathrm{mol} \mathrm{g}^{-1}\right)$. Fe is systematically closely associated with the organic crust at the surface of quartz grains as revealed by the concomitant presence of $\mathrm{Fe}$ and $\mathrm{C}$ (and also $\mathrm{Al}$ ) in EDX elemental maps (Fig. 2), and as previously shown (Cornelis et al., 2018). The reductive dissolution of Fe(III) in these Fe coatings may thus affect associated OC.

\subsection{Microbial Fe(III) reduction: rate and extent}

In all samples, the presence of $S$. putrefaciens under anoxic conditions ( $\mathrm{AB}$ treatments) induced an increase in $\mathrm{Fe}(\mathrm{II})$ concentrations as compared to control experiments without added cells (A experiments, Fig. 3). At the end of the incubation period, 2.8, 5.4 and 1.8 times more $\mathrm{Fe}(\mathrm{II})$ is released in $\mathrm{P}-270$ yrs $\mathrm{AB}, \mathrm{P}-330$ yrs $\mathrm{AB}$ and $\mathrm{P}-530$ yrs $\mathrm{AB}$, respectively, as compared to the corresponding controls free of $S$. $p u$ trefaciens cells P-270 yrs A, P-330 yrs A, P-530 yrs A.

Both the rate and extent of microbial Fe(III) reduction increase with increasing soil age. The amount of $\mathrm{Fe}(\mathrm{II})$ produced by $S$. putrefaciens amounts to $0.23,0.32$ and $1.98 \mu \mathrm{mol} \mathrm{g}^{-1}$ in P-270 yrs, P-330 yrs and P-

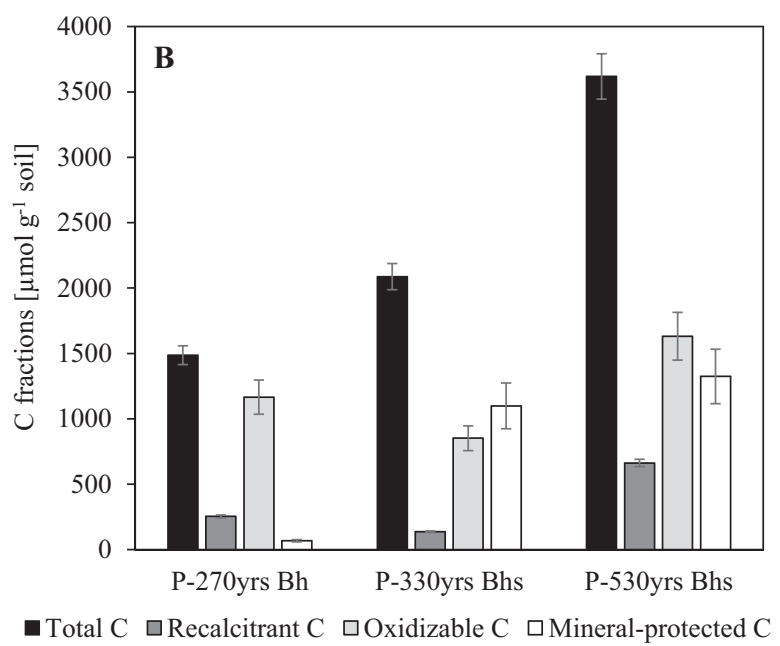

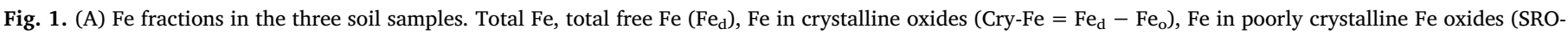

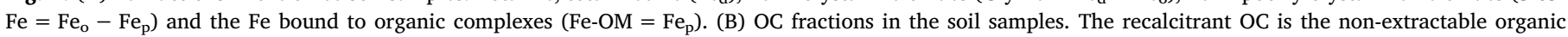

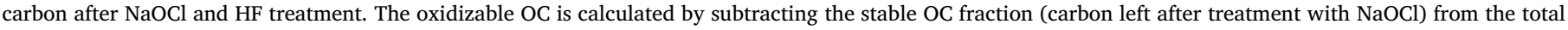
OC. The mineral-protected OC was calculated by subtracting the recalcitrant OC fraction from the stable OC fraction. 

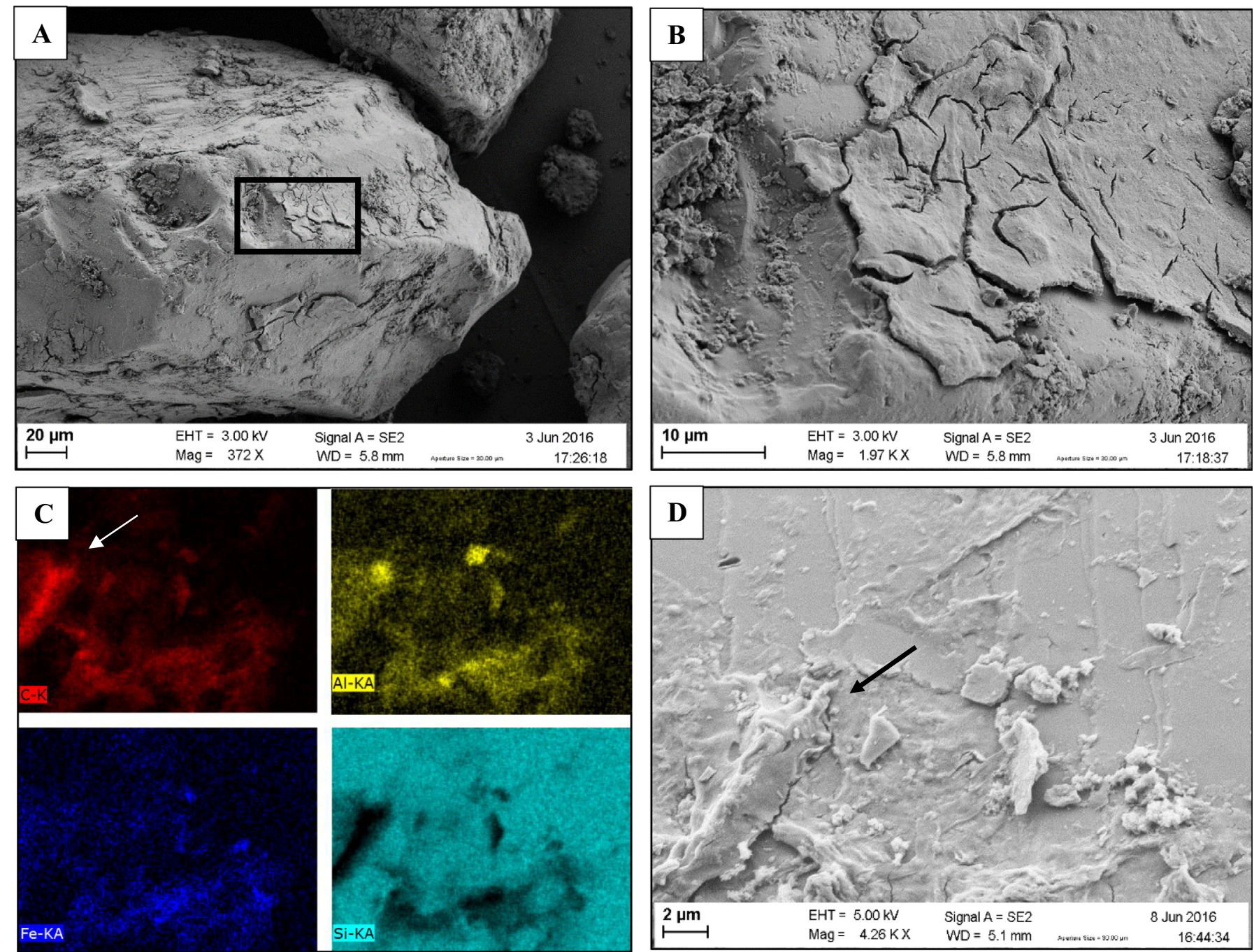

Fig. 2. (A) SEM micrographs of a representative quartz grain from the P-530 yrs soil sample coated with organic crust. Insert highlights the position of the zone illustrated in (B) on the quartz surface. (B) Detailed view of a representative organic crust covering large portion of the quartz grain. (C) EDX content maps of the organic crust showing the close spatial associations of $\mathrm{Si}, \mathrm{C}, \mathrm{Fe}$ and $\mathrm{Al}$ at the surface of the quartz grain (D) Corresponding SEM image of (C): the arrows are pointing on the same zone.

530 yrs, respectively (difference between $\mathrm{AB}$ and A treatment - Fig. 4). Reduction rates (calculated from linear least square regressions over time vs. Fe(II) concentrations during the first $6 \mathrm{~h}$ ) increase as well, from

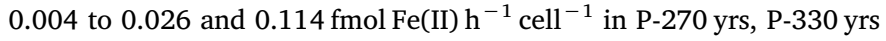
and P-530 yrs, respectively (Table 2). The initial Fe reduction rates are in the range of those observed by Bonneville et al. (2004) for ferrihydrite (i.e. $8.1 \times 10^{-2} \mathrm{fmol} \mathrm{h}^{-1}$ cell $^{-1}$ - also with $S$. putrefaciens). Microbial reduction extent and rates are both strongly and positively correlated with SRO-Fe content $\left(\mathrm{r}^{2}=0.98\right.$ and 0.99 , for extent and reduction rate, respectively) while correlation with crystalline Fe oxide amount is poor $\left(\mathrm{r}^{2}=0.27\right.$ and 0.15 for reduction extent and rate, respectively). Although crystalline Fe oxides such as lepidocrocite, goethite and hematite (Bonneville et al., 2009; Kukkadapu et al., 2001) and also structural Fe(III) in clay minerals (Kostka et al., 1996; Dong et al., 2009) can be used in DIR process, Fe(III) in SRO-Fe oxide(ferrihydrite) is preferentially used for Fe reduction in soils, sediments, and aquifers because of its high bioavailability to DIR bacteria (Fredrickson et al., 1998; Glasauer et al., 2003; Hansel et al., 2004; Bonneville et al., 2004; Zachara et al., 2002; Nealson and Myers, 1992; Lovley, 2013). Since the largest reduction occurred in the sample presenting the lowest total $\mathrm{P}$ content in soil samples $\left(0.40,0.34\right.$ and $0.16 \mathrm{~g} \mathrm{P} \mathrm{kg}^{-1}$ in P-270, P-330 and $\mathrm{P}-530$ yrs soil), and the lowest $\mathrm{pH}(\mathrm{pH}$ of the solution at the end of the incubations $\sim 5.3, \sim 5.7$ and $\sim 4.6$ for P-270, P-330 and P-530 yrs, respectively, Table 3 ), it seems reasonable to assume that the $\mathrm{P}$ concentrations and $\mathrm{pH}$ did not play a primary limiting role in our experiments.

$\mathrm{Fe}_{\mathrm{p}}$ content (Fe-OM) correlates, but less strongly, with the $\mathrm{Fe}(\mathrm{II})$ amount produced by $S$. putrefaciens $\left(\mathrm{r}^{2}=0.50\right)$. We hypothesize that $\mathrm{Fe}_{\mathrm{p}}$ might include Fe forms containing $\mathrm{Fe}(\mathrm{II})$ and/or $\mathrm{Fe}(\mathrm{III})$ bound to OM in stable complexes, thus unavailable for DIR bacteria (Haas and Dichristina, 2002). An argument in favor of the first hypothesis is that a substantial amount of DOC and dissolved Fe(II) is measured in control experiments free of $S$. putrefaciens (Fig. 3). In all incubations, except for experiment P-330 yrs A (i.e. anoxic control incubations with P-330 yrs), total dissolved $\mathrm{Fe}$ and $\mathrm{Fe}(\mathrm{II})$ concentrations are similar, if not quasi identical. Fe(II) is thus the major form of dissolved Fe (between 80 and $95 \%$ of total dissolved Fe, Fig. 3) that is likely stabilized by the OM and solubilized during re-wetting of the soil sample (Lovley et al., 1998; Kappler and Straub, 2005; Pédrot et al., 2011). Though Fe(III) represents a significant fraction of total dissolved Fe in P-330 yrs A $(\sim 54 \%)$, this does not necessarily imply that it is bioavailable. Haas and Dichristina (2002) have shown that reduction rates of Fe(III)-organic complexes are inversely correlated with the stability constants of these complexes, implying that chemical speciation governs $\mathrm{Fe}(\mathrm{III})$ 

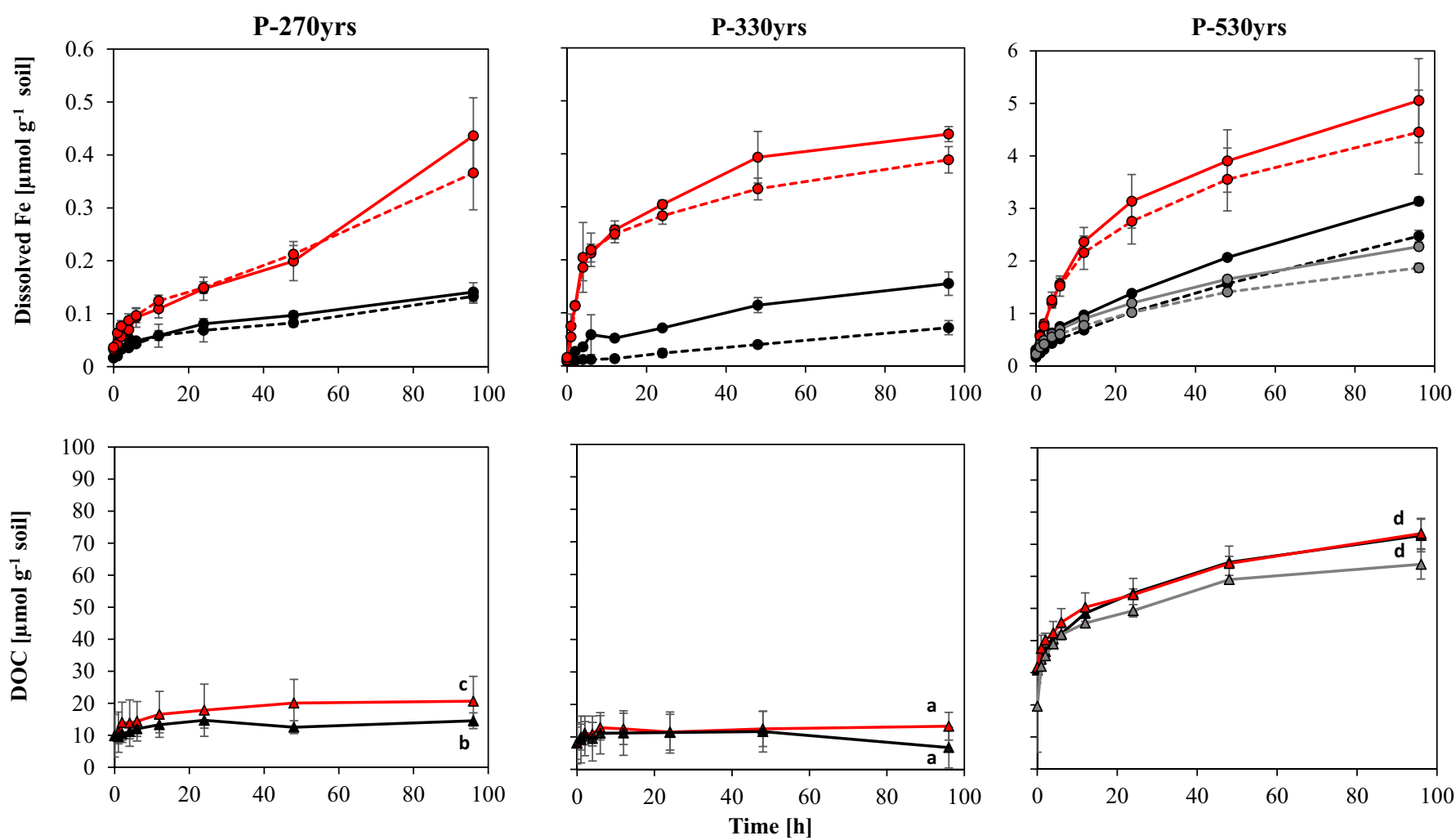

Soil + Saline solution $-\operatorname{anoxic}(\mathrm{A})$

Soil + Saline solution + Bacteria - anoxic $(\mathrm{AB})$

Soil + Saline solution + Bacteria - oxic $(\mathrm{OB})$

\begin{abstract}
Total dissolved $\mathrm{Fe} \quad-$
Dissolved Fe(II) -O-

DOC $-\Lambda$
\end{abstract}

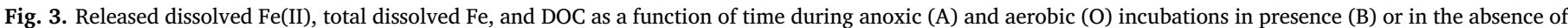

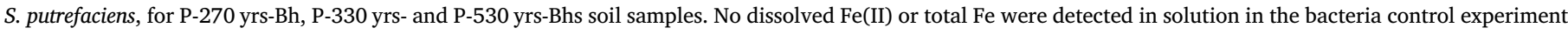

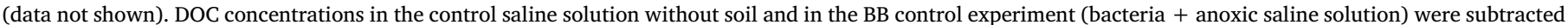

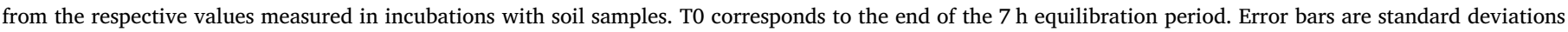

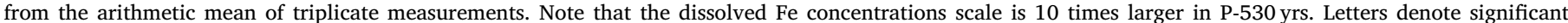

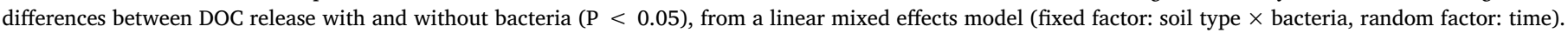
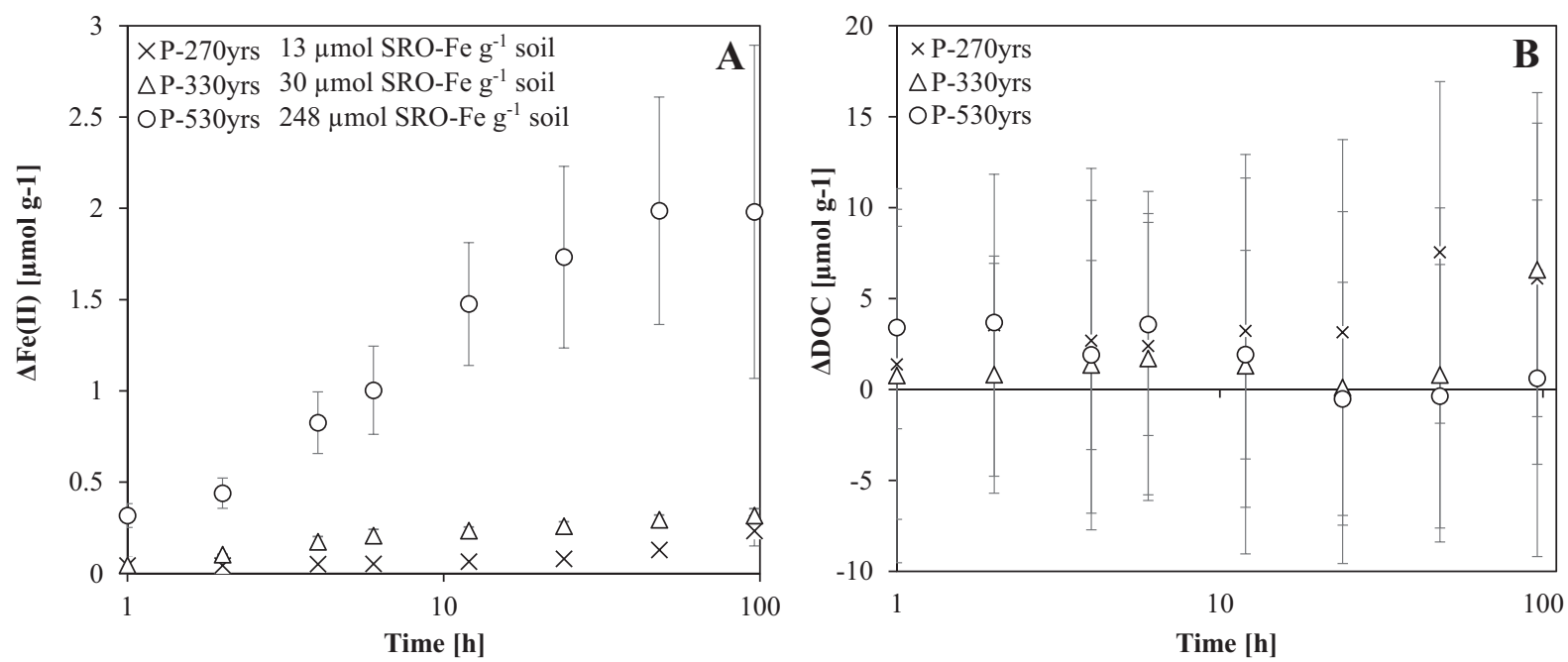

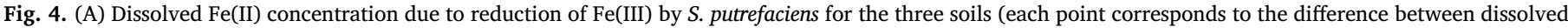

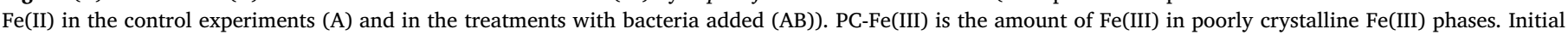

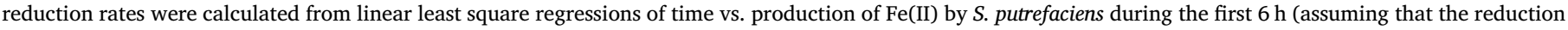

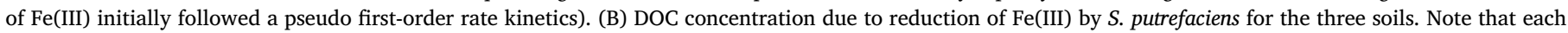
point corresponds to the difference between DOC in the control experiments (A) and in the treatments with bacteria added (AB). 
Table 2

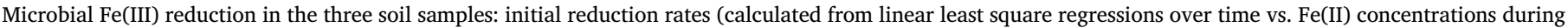

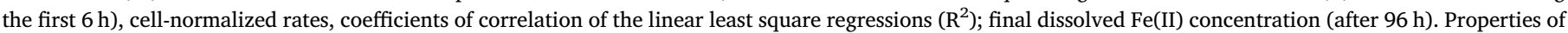

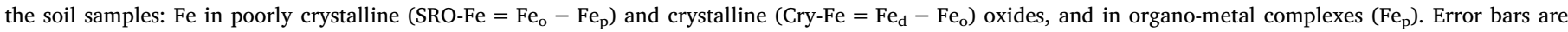
standard deviations from the arithmetic mean of triplicate measurements.

\begin{tabular}{|c|c|c|c|c|c|c|c|}
\hline \multirow[t]{3}{*}{ Sample } & \multicolumn{4}{|c|}{ Reduction by $S$. putrefaciens ${ }^{\mathrm{a}}$} & \multicolumn{3}{|c|}{ Properties of the solid phase } \\
\hline & \multicolumn{3}{|c|}{ Initial red. rates } & \multirow{2}{*}{$\frac{\text { Fe(II) released }}{\mu \mathrm{mol} \mathrm{g}}$} & \multirow{2}{*}{$\frac{\text { SRO-Fe }}{\mu \mathrm{mol} \mathrm{g}^{-1}}$} & \multirow{2}{*}{$\frac{\text { Cry-Fe }}{\mu \mathrm{mol} \mathrm{g}}$} & \multirow{2}{*}{$\frac{\mathrm{Fe}_{\mathrm{p}}}{\mu \mathrm{mol} \mathrm{g}}$} \\
\hline & $\mu \mathrm{mol} \mathrm{g}{ }^{-1} \mathrm{~h}^{-1}$ & Fmol h $^{-1}$ cell $^{-1}$ & $\mathrm{R}^{2}$ & & & & \\
\hline P-270 yrs & 0.005 & 0.004 & 0.82 & $0.23 \pm 0.08$ & $13.40 \pm 7.16$ & $8.58 \pm 5.55$ & $25.43 \pm 3.58$ \\
\hline P-330 yrs & 0.035 & 0.026 & 0.96 & $0.32 \pm 0.04$ & $30.20 \pm 44.40$ & $178.84 \pm 35.28$ & $178.32 \pm 25.43$ \\
\hline P-530 yrs & 0.154 & 0.114 & 0.98 & $1.98 \pm 0.91$ & $248.84 \pm 74.85$ & $0.00 \pm 62.67$ & $222.85 \pm 31.87$ \\
\hline
\end{tabular}

a The extent of microbial Fe(III) reduction is the difference at each time step between the dissolved Fe(II) concentration in A treatment (without bacteria added)

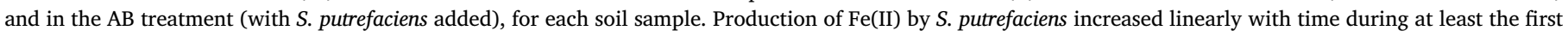
$6 \mathrm{~h}$ of incubation, for the three soils.

Table 3

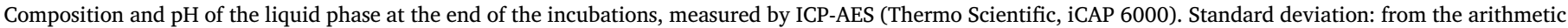
mean of triplicate measurements. < DL: below detection limit.

\begin{tabular}{|c|c|c|c|c|c|c|}
\hline \multirow[t]{2}{*}{ Treatment } & $\mathrm{K}$ & $\mathrm{Mg}$ & Mn & $\mathrm{P}$ & $\mathrm{S}$ & Final $\mathrm{pH}$ \\
\hline & $\mu \mathrm{M}$ & $\mu \mathrm{M}$ & $\mu \mathrm{M}$ & $\mu \mathrm{M}$ & $\mu \mathrm{M}$ & \\
\hline BB & $0.60 \pm 0.15$ & $9.65 \pm 2.28$ & $<\mathrm{DL}$ & $1.76 \pm 0.10$ & $6.50 \pm 0.92$ & 7.7 \\
\hline P-270 yrs A & $4.10 \pm 0.06$ & $21.33 \pm 1.32$ & $0.15 \pm 0.01$ & $0.20 \pm 0.01$ & $4.06 \pm 0.04$ & 5.4 \\
\hline P-270 yrs AB & $5.40 \pm 0.28$ & $39.47 \pm 4.05$ & $0.32 \pm 0.16$ & $0.57 \pm 0.06$ & $7.20 \pm 0.20$ & 5.2 \\
\hline P-330 yrs A & $3.79 \pm 0.72$ & $7.05 \pm 2.16$ & $<\mathrm{DL}$ & $<\mathrm{DL}$ & $6.95 \pm 1.04$ & 5.8 \\
\hline P-330 yrs AB & $10.05 \pm 7.25$ & $9.36 \pm 1.62$ & $<\mathrm{DL}$ & $0.68 \pm 0.10$ & $9.23 \pm 1.05$ & 5.7 \\
\hline P-530 yrs A & $3.32 \pm 0.23$ & $7.60 \pm 0.67$ & $0.16 \pm 0.01$ & $0.15 \pm 0.06$ & $7.63 \pm 0.19$ & 4.5 \\
\hline P-530 yrs AB & $13.96 \pm 7.33$ & $11.19 \pm 4.33$ & $0.14 \pm 0.02$ & $0.19 \pm 0.05$ & $9.12 \pm 2.76$ & 4.7 \\
\hline P-530 yrs OB & $5.35 \pm 2.46$ & $9.29 \pm 1.32$ & $0.13 \pm 0.01$ & $0.19 \pm 0.07$ & $8.19 \pm 1.93$ & 4.6 \\
\hline
\end{tabular}

bioavailability of these complexes.

\subsection{Influence of microbial $\mathrm{Fe}(\mathrm{III})$ reduction on OM release}

In all experiments, DOC release starts immediately after exposure of the sample to sterile saline solution, and reaches $\sim 10, \sim 8$ and $\sim 31 \mu \mathrm{mol} \mathrm{C}^{-1}$ soil for P-270 yrs, P-330 yrs and P-530 yrs, respectively at the end of a $7 \mathrm{~h}$ equilibration period (i.e., t0, the time just before cell addition). In all treatments, DOC concentration continues to increase linearly over the first $6 \mathrm{~h}$ of incubation with $S$. putrefaciens (t1 to t4), before leveling off at $\sim 18$ and $\sim 10 \mu \mathrm{mol} \mathrm{g}^{-1}$ soil for P-270 yrs and P330 yrs $\mathrm{AB}$ and $\mathrm{A}$ experiments (i.e., anoxic with and without $S$. putrefaciens). In P-530 yrs $\mathrm{AB}$ and $\mathrm{A}$ experiments, however, the DOC concentration keeps increasing to reach $\sim 73 \mu \mathrm{mol} \mathrm{g}^{-1}$ after $96 \mathrm{~h}$ (t8). The DOC caused by DIR processes $(\triangle \mathrm{DOC})$ is the difference in DOC concentrations between (i) control treatment free of bacteria and (ii) incubation treatment with $S$. putrefaciens. As illustrated in Figs. 3 and $4 \mathrm{~B}, \triangle \mathrm{DOC}$ is limited, despite active microbial Fe(III) reduction. In P330 yrs and P-530 yrs, the evolution of $\triangle \mathrm{DOC}$ against time does not show any clear trend. In P-270 yrs, $\triangle \mathrm{DOC}$ increases over time from 1.3 to a maximum of $\sim 7.5 \mu \mathrm{mol} \mathrm{C} \mathrm{g}{ }^{-1}$ at $96 \mathrm{~h}$ (Fig. 4B). That increase of $\triangle \mathrm{DOC}$ is statistically significant in P-270 yrs, but not in P-330 yrs and P530 yrs $($ Chisq $=26.119, \mathrm{Df}=2, \operatorname{Pr}(>$ Chisq $)=2.129 \mathrm{e}-06$; from a linear mixed effects model - fixed factor: soil $\times$ bacteria, random factor: time, Fig. 3). Considering (i) a theoretical ferrihydrite (Fe $(\mathrm{OH})_{3}-106.9 \mathrm{~g} \mathrm{~mol}^{-1}$ ) specific surface area of $600 \mathrm{~m}^{2} \mathrm{~g}^{-1}$ (Kleber et al., 2015), (ii) a surface adsorption capacity of $0.52 \mathrm{mg} \mathrm{OC} \mathrm{m}^{-2}$, (iii) a coprecipitation OC loading of $1.1 \mathrm{mg} \mathrm{OC} \mathrm{m}^{-2}$ (Eusterhues et al., 2014), we converted the $\mathrm{Fe}(\mathrm{II})$ amount produced by $S$. putrefaciens into a theoretical ferrihydrite surface area loss, and the potential DOC release associated with DIR reactions. This theoretical DOC release should reach $0.6,0.9$ and $5.5 \mu \mathrm{mol}$ of adsorbed OC and 1.3, 1.9 and $11.6 \mu \mathrm{mol}$ coprecipitated OC in P-270 yrs, P-330 yrs and P-530 yrs, respectively. Despite uncertainties of $\triangle \mathrm{DOC}$ measurement and limitations of above calculations, experimental and theoretical values of DOC release are in line with each other.

The limited extent of microbial Fe(III) reduction $(1.7,1.1$ and $0.8 \%$ of the initial SRO-Fe pool in P-270, P-330 and P-530 yrs, respectively) might explain the modest DOC release observed here. This is somehow surprising since appreciable amounts of DOC - a source of electron donor for DIR reactions - and SRO-Fe(III) phases are present at the end of incubation. One possible explanation might be that the DOC released during the $75 \mathrm{~h}$ equilibration period was of low availability for $S$. putrefaciens, hence limiting the extent of microbial Fe(III) reduction. It is also possible that $\mathrm{Fe}(\mathrm{III})$ mineral surfaces were physically inaccessible to Fe reducing bacteria due to adsorbed OM, blocking surface sites and impacting aggregation (Amstaetter et al., 2012). The inaccessibility of $\mathrm{Fe}(\mathrm{III})$ phases to Fe reducing bacteria has been invoked in riverine sediment settings to explain the discrepancy between the extent of (i) microbial $\mathrm{Fe}(\mathrm{III})$ reduction and (ii) reductive extraction by ascorbate (Hyacinthe et al., 2006). In this respect, Cornelis et al. (2018) highlighted a mutual protection mechanism involving Fe protection within Fe-OMA as well as OM protection through coprecipitation and/or adsorption.

DOC oxidation to $\mathrm{CO}_{2}$ or $\mathrm{HCO}_{3}{ }^{-}$during DIR reactions might also explain the limited DOC release after $S$. putrefaciens addition. Oxidation consumes DOC and might mask a possible DOC release due to reductive dissolution of OMA. Considering the stoichiometry of ferrihydrite (Fe $(\mathrm{OH})_{3}$ ) reduction reaction coupled to OM oxidation (Bonneville, 2005), $\left[4 \mathrm{Fe}(\mathrm{OH})_{3}+7 \mathrm{H}^{+}+{ }^{\prime} \mathrm{CH}_{2} \mathrm{O}\right.$ ' $\left.\rightarrow 4 \mathrm{Fe}^{2+}+10 \mathrm{H}_{2} \mathrm{O}+\mathrm{HCO}_{3}{ }^{-}\right], 4 \mathrm{~mol}$ of $\mathrm{Fe}(\mathrm{II})$ and $1 \mathrm{~mol}$ of $\mathrm{HCO}_{3}{ }^{-}$are produced per mole of organic carbon consumed. Applying the same stoichiometry to our data, for instance for the most reactive P-530 yrs $\mathrm{AB}$, release of $1.98 \mu \mathrm{mol}$ of $\mathrm{Fe}(\mathrm{II}) \mathrm{g}^{-1}$ after $S$. putrefaciens addition would correspond to $0.495 \mu \mathrm{mol} \mathrm{OC} \mathrm{g}^{-1}$ consumed by oxidation $\left(<0.1 \mu \mathrm{molOC} \mathrm{g}^{-1}\right.$ for P-270 yrs and P$330 \mathrm{yrs})$. Even though this generalized, stoichiometry calculation should be considered with caution, it reveals that overall, DOC consumption via DIR reactions cannot affect drastically the overall DOC 
dynamics in our experiments.

Several studies argue that DOC release during reducing events occurs in response to $\mathrm{pH}$ increase (Avena and Koopal, 1998; Kalbitz et al., 2000). In wetland soils, Grybos et al. (2009) showed that the increase of $\mathrm{pH}$ accounts for $60 \%$ of DOC release. Here, no increase of $\mathrm{pH}$ is observed (Table 3).

Our results, showing limited DOC release due to DIR $(\triangle \mathrm{DOC})$, are in line with previous studies showing no significant additional release of DOC during anoxic events in organic-rich soil horizons (Moore and Dalva, 2001; Fiedler and Kalbitz, 2003). Here, the most important process of DOC release is likely the direct solubilization of organic matter after re-wetting, while DIR-related DOC release is less important. Kalbitz et al. (2000) pointed out that the increase of DOC concentration resulting from rewetting after dry periods occurs in both field and laboratory studies. These authors further propose three possible explanations: (i) because of slow OM decomposition during dry periods, microbial products accumulate and are released upon rewetting; (ii) cell death and lysis due to soil desiccation also accumulate microbial products that are released upon rewetting; (iii) cracking due to desiccation renders previously 'protected' organic carbon available for solubilization after rewetting.

\subsection{Influence of OM on microbial Fe(III) reduction}

OM components may accelerate microbial reduction through several mechanisms. First, they can act as electron shuttles, with quinones and flavins being the most redox active compounds (Roden et al., 2010; Hansel et al., 2004; Jiang and Kappler, 2008; Aeschbacher et al., 2009). Second, they bind with dissolved Fe(II) thereby increasing the driving force for Fe(III) reduction (Royer et al., 2002). Third, they act as a ligand towards Fe(III), thereby promoting Fe solubilization (Jones et al., 2009). Fourth, they control the structure and reactivity (crystallinity) of natural Fe oxides when coprecipitated (Zachara et al., 2002; Von Lützow et al., 2006; Eusterhues et al., 2008; Cornell and Schwertmann, 2003). To the contrary, OM may also decrease microbial reduction by passivating Fe mineral surfaces by blocking surface sites or initiating aggregation (Bonneville et al., 2006; Amstaetter et al., 2012).

Electron shuttling is a well-known strategy of $S$. putrefaciens to reduce Fe(III) phases beyond their near-environment (Marsili et al., 2008; Kotloski and Gralnick, 2013; Newman, 2001). However, electron shuttling becomes significant at concentrations above $3-10 \mathrm{mg} \mathrm{OC} \mathrm{L}^{-1}$ (Poggenburg et al., 2016; Jiang and Kappler, 2008), this threshold value being highly dependent on OM composition. Thus, in P-270 yrs and P-330 yrs, the DOC concentrations ranging from 2.01 to $6.19 \mathrm{mg} \mathrm{OC} \mathrm{L}^{-1}$ are probably too low for efficient electron shuttling to occur. However, electron shuttling may have contributed to enhanced microbial Fe(III) reduction observed in P-530 yrs - where DOC reached $22.0 \mathrm{mg} \mathrm{OC} \mathrm{L}^{-1}$ - compared to younger podzol. Conversely, DOC (including a potential production of chelators by the cells themselves) may also have complexed dissolved Fe(II), as suggested by the positive correlations between the two parameters $\left(\mathrm{r}^{2}=0.77,0.77\right.$ and 0.99 for P-270, P-330 and P-530 yrs, respectively, for the treatments AB). Supported by the ample DOC pool compared to Fe(II) concentration (one order of magnitude difference), Fe complexation may have limited Fe (II) re-adsorption onto bacteria and mineral surfaces, and, as such, slightly increased the thermodynamic gain of DIR. Shewanella putrefaciens is also known to produce an Fe(III)-solubilizing organic ligand during anaerobic respiration (Taillefert et al., 2007). This might have played a role in our incubations.

The main impact of OM on the microbial Fe(III) reduction could be here related to its control of the crystallinity of $\mathrm{Fe}(\mathrm{III})$ phases along the soil chronosequence. The evolution of Fe mineralogy can be assessed by the $\mathrm{Fe}_{\mathrm{o}}: \mathrm{Fe}_{\mathrm{d}}$ ratio as related to total OC (Cornell and Schwertmann, 2003). In P-270 yrs., there is a relatively high amount of OM combined with a low total $\mathrm{Fe}$ content $\left(\right.$ molar $\mathrm{C}_{\mathrm{total}}: \mathrm{Fe}_{\mathrm{d}}$ ratio $=31.3$ ), thus most of the Fe is likely bound to OM as Fe-OM complexes. In P-330 yrs., the dominance of crystalline $\mathrm{Fe}(\mathrm{III})$ oxides $\left(\mathrm{Fe}_{\mathrm{o}}: \mathrm{Fe}_{\mathrm{d}}=0.54\right)$ is likely due to the relatively low content of OM (molar $\mathrm{C}_{\text {total }}: \mathrm{Fe}_{\mathrm{d}}$ ratio is the lowest of the three soil sample at 5.4). In this case, SRO-Fe(III) oxides readily form, and can evolve into crystalline Fe(III) oxides (Cry-Fe is the dominant phase, Fig. 1). In contrast, in P-530 yrs, high amounts of Fe promotes the precipitation of SRO-Fe(III) oxides $\left(\mathrm{Fe}_{\mathrm{o}}: \mathrm{Fe}_{\mathrm{d}}\right.$ : 1.01 ; Fig. 1). However, the large amount of OM present might have hindered, or at least slowed down, its transformation towards more stable, crystalline $\mathrm{Fe}(\mathrm{III})$ phases (molar $\mathrm{C}_{\text {total }}: \mathrm{Fe}_{\mathrm{d}}=7.7$ ).

\section{Conclusions and natural implications}

The objective of this study was to assess the impact of DIR on Fe(II) and DOC release in 3 spodic illuvial horizons of increasing age. With increasing soil age and podzol development, both the rate and extent of microbial Fe(III) reduction increased. In all treatments, a significant amount of DOC was released. Despite active microbial Fe(III) reduction, the release of DOC related to DIR reactions is limited in all soil horizons but is significant in P-270 yrs (at most $7.5 \mu \mathrm{mol} \mathrm{OC} \mathrm{g}^{-1}$ ). Overall, our results suggest that the main control of DOC release in our incubation is not related to DIR reactions but rather to the re-wetting process of soil sample and the direct solubilization of OM. We conclude that the amount of accumulated OM affects the crystallinity of Fe(III) phases in podzols and, thus, impact the rate and extent of microbial Fe(III) reduction.

In the field, we observed a cementation/induration of the spodic illuvial B horizons, particularly in P-330 yrs and P-530 yrs Bhs, due to the accumulation of $\mathrm{Al}, \mathrm{Fe}$ and $\mathrm{OM}$ in pore space (Vermeire et al., 2018). Pore clogging thus occurs and impedes water infiltration. During rainy periods, poor drainage may cause episodic waterlogging and thus induce anoxic events in the illuvial B horizon. Given the ubiquitous character of DIR (Lovley, 2013), our results suggest that such anoxic episodes will lead to the production of dissolved Fe(II), which will eventually re-oxidize to form Fe oxides (Ginn et al., 2017). The crystallinity of those neoformed Fe(III) phases will depend on (i) the amount of redox cycles (Thompson et al., 2006), (ii) the Fe(II) re-oxidation kinetics, duration of $\mathrm{O}_{2}$ exposure (Thompson, 2016), and (iii) the chemical composition of the soil solution, notably the concentrations of OM, as shown here, or of various ions (Zachara et al., 2002). Subsequently, under the action of the soil microbial community (Vermeire et al., 2018), the nature of the resulting Fe(III) phases will have an impact on OM stabilization, and on Fe(III) bioavailability as redox cycles occur (Coward et al., 2018). Further research on the complex interplay between in-situ redox conditions and drying/wetting cycles are required to understand better the formation and the evolution of OMA during podzolization, and their consequences on DIR process.

\section{Conflict of interest statement}

The authors declare that the research was conducted in the absence of any commercial or financial relationships that could be construed as a potential conflict of interest.

\section{Abbreviations}

Cry-Fe $\quad$ Fe in crystalline Fe oxides

DIR dissimilatory iron reduction

DOC dissolved organic carbon

$\mathrm{Fe}_{\mathrm{d}} \quad$ DCB-extractable Fe

$\mathrm{Fe}_{\mathrm{o}} \quad$ oxalate-extractable $\mathrm{Fe}$

$\mathrm{Fe}_{\mathrm{p}} \quad$ pyrophosphate-extractable $\mathrm{Fe}$

$\mathrm{Fe}_{\mathrm{t}}$ total $\mathrm{Fe}$

OC organic carbon

OM organic matter

OMA organo-mineral associations 
SRO-Fe Fe in short-range-ordered (SRO) oxides

\section{Treatments}

A $\quad$ Soil + Saline solution - anoxic

$\mathrm{AB} \quad$ Soil + Saline solution + Bacteria - anoxic

$\mathrm{OB} \quad$ Soil + Saline solution + Bacteria - aerobic

\section{Acknowledgements}

We thank A. Iserentant, C. Givron and L. Ryelandt (Université Catholique de Louvain (UCL), Belgium) for the analysis with the ICPAES and help with labwork, and for the SEM-EDX analysis. Les Lavkulich is acknowledged for his help during fieldwork. We also thank Eric Van Ranst and Florias Mees (Ghent University) for the thin sections preparation, and Simon Power (University of Cape Town) for his help with the statistics. Financial support was provided by the Belgian Fond de la Recherche Scientifique (F.R.S.-FNRS, FRFC project 2.4590.12.). Our thanks are extended to the members of the GEBI (UCL) for their help with the microbiology and financial support, provided by the Interuniversity Attraction Poles (IUAP VII Networks) of the Belgian Science Policy Office (BELSPO, project P7/25, Microbial Resource Management (MRM) in engineered and natural ecosystems (m-manager)). SB benefited from the support of the "Victor Brien" and "Van Buuren" funds as well as the F.R.S.-FNRS (PDR T.1012.14).

\section{References}

Adhikari, D., Poulson, S.R., Sumaila, S., Dynes, J.J., Mcbeth, J.M., Yang, Y., 2016. Asynchronous reductive release of iron and organic carbon from hematite-humic acid complexes. Chem. Geol. 430, 13-20.

Adhikari, D., Zhao, Q., Das, K., Mejia, J., Huang, R., Wang, X., Poulson, S.R., Tang, Y., Roden, E.E., Yang, Y., 2017. Dynamics of ferrihydrite-bound organic carbon during microbial Fe reduction. Geochim. Cosmochim. Acta 212, 221-233.

Aeschbacher, M., Sander, M., Schwarzenbach, R.P., 2009. Novel electrochemical approach to assess the redox properties of humic substances. Environ. Sci. Technol. 44, 87-93.

AFNOR, 2006. Qualité du sol - Prétraitement des échantillons pour analyses physicochimiques. NF ISO 11464, Décembre 2006.

AGILENT BioCalculators [online]. Available: https://www.genomics.agilent.com/ bioCalcs.jsp, Accessed date: 16 August 2018.

Amstaetter, K., Borch, T., Kappler, A., 2012. Influence of humic acid imposed changes of ferrihydrite aggregation on microbial Fe (III) reduction. Geochim. Cosmochim. Acta 85, 326-341.

Avena, M.J., Koopal, L.K., 1998. Desorption of humic acids from an iron oxide surface. Environ. Sci. Technol. 32, 2572-2577.

Avena, M.J., Koopal, L.K., 1999. Kinetics of humic acid adsorption at solid-water interfaces. Environ. Sci. Technol. 33, 2739-2744.

Baldock, J.A., Skjemstad, J., 2000. Role of the soil matrix and minerals in protecting natural organic materials against biological attack. Org. Geochem. 31, 697-710.

Bascomb, C.L., 1968. Distribution of pyrophosphate-extractable iron and organic carbon in soils of various groups. J. Soil Sci. 19, 251-268.

Bates, D., Maechler, M., Bolker, B., Walker, S., 2015. Fitting linear mixed-effects models using lme4. J. Stat. Softw. 67.

Blakemore, L.C., Searle, P.L., Daly, B.K., 1987. Methods for Chemical Analysis of Soils. New Zealand Soil Bureau, Lower Hutt, N.Z.

Bonneville, S., 2005. Kinetics of Microbial Fe (III) Oxyhydroxidereduction: The Role of Mineral Properties (Ph.D. Dissertation). Universiteit Utrecht.

Bonneville, S., Vancappellen, P., Behrends, T., 2004. Microbial reduction of iron(III) oxyhydroxides: effects of mineral solubility and availability. Chem. Geol. 212, 255-268.

Bonneville, S., Behrends, T., Van Cappellen, P., Hyacinthe, C., Röling, W.F., 2006. Reduction of Fe (III) colloids by Shewanella putrefaciens: a kinetic model. Geochim. Cosmochim. Acta 70, 5842-5854.

Bonneville, S., Behrends, T., Van Cappellen, P., 2009. Solubility and dissimilatory reduction kinetics of iron (III) oxyhydroxides: a linear free energy relationship. Geochim. Cosmochim. Acta 73, 5273-5282.

Buettner, S.W., Kramer, M.G., Chadwick, O.A., Thompson, A., 2014. Mobilization of colloidal carbon during iron reduction in basaltic soils. Geoderma 221-222, 139-145.

Buurman, P., Jongmans, A.G., 2005. Podzolisation and soil organic matter dynamics. Geoderma 125, 71-83.

Claessens, J., Van Lith, Y., Laverman, A.M., Van Cappellen, P., 2006. Acid-base activity of live bacteria: implications for quantifying cell wall charge. Geochim. Cosmochim. Acta $70,267-276$.

Cooper, R.E., Eusterhues, K., Wegner, C.-E., Totsche, K.U., Küsel, K., 2017. Ferrihydriteassociated organic matter (OM) stimulates reduction by Shewanella oneidensis MR-1 and a complex microbial consortia. Biogeosciences 14, 5171.
Cornelis, J.-T., Weis, D., Lavkulich, L., Vermeire, M.-L., Delvaux, B., Barling, J., 2014. Silicon isotopes record dissolution and re-precipitation of pedogenic clay minerals in a podzolic soil chronosequence. Geoderma 235-236, 19-29.

Cornelis, J.T., Delvaux, B., Van Ranst, E., Rouxhet, P.G., 2018. Sub-micrometer distribution of Fe oxides and organic matter in podzol horizons. Geoderma 323, $126-135$.

Cornell, R.M., Schwertmann, U., 2003. The Iron Oxides: Structure, Properties, Reactions, Occurrences and Uses. John Wiley \& Sons.

Coward, E.K., Thompson, A., Plante, A.F., 2018. Contrasting Fe speciation in two humid forest soils: insight into organomineral associations in redox-active environments. Geochim. Cosmochim. Acta 238, 68-84.

Do Nascimento, N., Bueno, G., Fritsch, E., Herbillon, A., Allard, T., Melfi, A., Astolfo, R., Boucher, H., Li, Y., 2004. Podzolization as a deferralitization process: a study of an acrisol-podzol sequence derived from Palaeozoic sandstones in the northern upper Amazon Basin. Eur. J. Soil Sci. 55, 523-538.

Dong, H., Jaisi, D.P., Kim, J., Zhang, G., 2009. Review paper. Microbe-clay mineral interactions. Am. Mineral. 94, 1505-1519.

Eusterhues, K., Wagner, F.E., Häusler, W., Hanzlik, M., Knicker, H., Totsche, K.U., KögelKnabner, I., Schwertmann, U., 2008. Characterization of ferrihydrite-soil organic matter coprecipitates by X-ray diffraction and Mossbauer spectroscopy. Environ. Sci. Technol. 42, 7891-7897.

Eusterhues, K., Hädrich, A., Neidhardt, J., Küsel, K., Keller, T.F., Jandt, K.D., Totsche, K.U., 2014. Reduction of ferrihydrite with adsorbed and coprecipitated organic matter: microbial reduction by Geobacter bremensis vs. abiotic reduction by Na-dithionite. Biogeosciences 11, 4953-4966.

Fiedler, S., Kalbitz, K., 2003. Concentrations and properties of dissolved organic matter in forest soils as affected by the redox regime. Soil Sci. 168, 793-801.

Fox, J., Weisberg, S., 2011. An R Companion to Applied Regression, 2nd edn. (CA, Thousand Oaks).

Fredrickson, J.K., Zachara, J.M., Kennedy, D.W., Dong, H., Onstott, T.C., Hinman, N.W., Li, S.-M., 1998. Biogenic iron mineralization accompanying the dissimilatory reduction of hydrous ferric oxide by a groundwater bacterium. Geochim. Cosmochim. Acta 62, 3239-3257.

Fritsch, E., Balan, E., Do Nascimento, N.R., Allard, T., Bardy, M., Bueno, G., Derenne, S., Melfi, A.J., Calas, G., 2011. Deciphering the weathering processes using environmental mineralogy and geochemistry: towards an integrated model of laterite and podzol genesis in the Upper Amazon Basin. Compt. Rendus Geosci. 343, 188-198.

Ginn, B., Meile, C., Wilmoth, J., Tang, Y., Thompson, A., 2017. Rapid iron reduction rates are stimulated by high-amplitude redox fluctuations in a tropical forest soil. Environ. Sci. Technol. 51, 3250-3259.

Glasauer, S., Weidler, P.G., Langley, S., Beveridge, T.J., 2003. Controls on Fe reduction and mineral formation by a subsurface bacterium. Geochim. Cosmochim. Acta 67, 1277-1288.

Grand, S., Lavkulich, L.M., 2013. Potential influence of poorly crystalline minerals on soil chemistry in podzols of southwestern Canada. Eur. J. Soil Sci. 64, 651-660.

Grybos, M., Davranche, M., Gruau, G., Petitjean, P., 2007. Is trace metal release in wetland soils controlled by organic matter mobility or Fe-oxyhydroxides reduction? J. Colloid Interface Sci. 314, 490-501.

Grybos, M., Davranche, M., Gruau, G., Petitjean, P., Pédrot, M., 2009. Increasing pH drives organic matter solubilization from wetland soils under reducing conditions. Geoderma 154, 13-19.

Haas, J.R., Dichristina, T.J., 2002. Effects of Fe (III) chemical speciation on dissimilatory Fe (III) reduction by Shewanella putrefaciens. Environ. Sci. Technol. 36, 373-380.

Hagedorn, F., Kaiser, K., Feyen, H., Schleppi, P., 2000. Effects of redox conditions and flow processes on the mobility of dissolved organic carbon and nitrogen in a forest soil. J. Environ. Qual. 29, 288-297.

Hansel, C.M., Benner, S.G., Nico, P., Fendorf, S., 2004. Structural constraints of ferric (hydr) oxides on dissimilatory iron reduction and the fate of Fe (II). Geochim. Cosmochim. Acta 68, 3217-3229.

Hau, H.H., Gralnick, J.A., 2007. Ecology and biotechnology of the genus Shewanella. Annu. Rev. Microbiol. 61, 237-258.

Hedges, J.I., Keil, R.G., 1995. Sedimentary organic matter preservation: an assessment and speculative synthesis. Mar. Chem. 49, 81-115.

Henderson, R., Kabengi, N., Mantripragada, N., Cabrera, M., Hassan, S., Thompson, A., 2012. Anoxia-induced release of colloid- and nanoparticle-bound phosphorus in grassland soils. Environ. Sci. Technol. 46, 11727-11734.

Henneberry, Y.K., Kraus, T.E., Nico, P.S., Horwath, W.R., 2012. Structural stability of coprecipitated natural organic matter and ferric iron under reducing conditions. Org. Geochem. 48, 81-89.

Hyacinthe, C., Bonneville, S., Van Cappellen, P., 2006. Reactive iron (III) in sediments: chemical versus microbial extractions. Geochim. Cosmochim. Acta 70, 4166-4180.

Jeanroy, E., Guillet, B., 1981. The occurrence of suspended ferruginous particles in pyrophosphate extracts of some soil horizons. Geoderma 26, 95-105.

Jiang, J., Kappler, A., 2008. Kinetics of microbial and chemical reduction of humic substances: implications for electron shuttling. Environ. Sci. Technol. 42, 3563-3569.

Jones, A.M., Collins, R.N., Rose, J., Waite, T.D., 2009. The effect of silica and natural organic matter on the Fe(II)-catalysed transformation and reactivity of Fe(III) minerals. Geochim. Cosmochim. Acta 73, 4409-4422.

Jones, A.R., Sanderman, J., Allen, D., Dalal, R., Schmidt, S., 2015. Subtropical giant podzol chronosequence reveals that soil carbon stabilisation is not governed by litter quality. Biogeochemistry 124, 205-217.

Kalbitz, K., Solinger, S., Park, J.-H., Michalzik, B., Matzner, E., 2000. Controls on the dynamics of dissolved organic matter in soils: a review. Soil Sci. 165, 277-304.

Kanev, V., 2011. Dynamics of acid-soluble iron compounds in soddy-podzolic soils of the southern Komi Republic. Eurasian Soil Sci. 44, 1201-1214.

Kappler, A., Straub, K.L., 2005. Geomicrobiological cycling of Iron. Rev. Mineral. 
Geochem. 59, 85-108

Keiluweit, M., Nico, P.S., Kleber, M., Fendorf, S., 2016. Are oxygen limitations under recognized regulators of organic carbon turnover in upland soils? Biogeochemistry $127,157-171$.

Kleber, M., Mikutta, R., Torn, M.S., Jahn, R., 2005. Poorly crystalline mineral phases protect organic matter in acid subsoil horizons. Eur. J. Soil Sci. 56, 717-725.

Kleber, M., Eusterhues, K., Keiluweit, M., Mikutta, C., Mikutta, R., Nico, P.S., 2015. Chapter one-mineral-organic associations: formation, properties, and relevance in soil environments. Adv. Agron. 130, 1-140.

Knorr, K.-H., 2013. DOC-dynamics in a small headwater catchment as driven by redox fluctuations and hydrological flow paths-are DOC exports mediated by iron reduction/oxidation cycles? Biogeosciences 10, 891-904.

Kögel-Knabner, I., Guggenberger, G., Kleber, M., Kandeler, E., Kalbitz, K., Scheu, S., Eusterhues, K., Leinweber, P., 2008. Organo-mineral associations in temperate soils: integrating biology, mineralogy, and organic matter chemistry. J. Plant Nutr. Soil Sci. $171,61-82$.

Kögel-Knabner, I., Amelung, W., Cao, Z., Fiedler, S., Frenzel, P., Jahn, R., Kalbitz, K., Kölbl, A., Schloter, M., 2010. Biogeochemistry of paddy soils. Geoderma 157, 1-14.

Kostka, J.E., Stucki, L.J.W., Nealson, K.H., Wu, J., 1996. Reduction of structural Fe (III) in smectite by a pure culture of the Fe-reducing bacterium Shewanella putrefaciens strain MR-1. Clay Clay Miner. 44, 522-529.

Kotloski, N.J., Gralnick, J.A., 2013. Flavin electron shuttles dominate extracellular electron transfer by Shewanella oneidensis. MBio 4 (e00553-12).

Kukkadapu, R.K., Zachara, J.M., Smith, S.C., Fredrickson, J.K., Liu, C., 2001. Dissimilatory bacterial reduction of Al-substituted goethite in subsurface sediments. Geochim. Cosmochim. Acta 65, 2913-2924.

Lovley, D., 2013. Dissimilatory Fe(III)- and Mn(IV)-reducing prokaryotes. In: Rosenberg, E., Delong, E.F., Lory, S., Stackebrandt, E., Thompson, F. (Eds.), The Prokaryotes: Prokaryotic Physiology and Biochemistry. Springer Berlin Heidelberg, Berlin, Heidelberg.

Lovley, D., Fraga, J.L., Blunt-Harris, E.L., Hayes, L., Phillips, E., Coates, J.D., 1998. Humic substances as a mediator for microbially catalyzed metal reduction. Acta Hydrochim. Hydrobiol. 26, 152-157.

Macdonell, M.T., Colwell, R.R., 1985. Phylogeny of the Vibrionaceae, and recommendation for two new genera, Listonella and Shewanella. Syst. Appl. Microbiol. 6, 171-182.

Marsili, E., Baron, D.B., Shikhare, I.D., Coursolle, D., Gralnick, J.A., Bond, D.R., 2008 Shewanella secretes flavins that mediate extracellular electron transfer. Proc. Natl. Acad. Sci. 105, 3968-3973.

Mehra, O.P., Jackson, M.L., 1960. Iron oxide removal from soils and clays by a dithionitecitrate system buffered with sodium bicarbonate. Clay Clay Miner. 7, 317-327.

Melton, E.D., Swanner, E.D., Behrens, S., Schmidt, C., Kappler, A., 2014. The interplay of microbially mediated and abiotic reactions in the biogeochemical Fe cycle. Nat. Rev. Microbiol. 12, 797-808.

Mikutta, R., Kleber, M., Torn, M.S., Jahn, R., 2006. Stabilization of soil organic matter: association with minerals or chemical recalcitrance? Biogeochemistry 77, 25-56.

Mikutta, C., Mikutta, R., Bonneville, S., Wagner, F., Voegelin, A., Christl, I., Kretzschmar, R., 2008. Synthetic coprecipitates of exopolysaccharides and ferrihydrite. Part I: characterization. Geochim. Cosmochim. Acta 72, 1111-1127.

Montes, C.R., Lucas, Y., Pereira, O.J.R., Achard, R., Grimaldi, M., Melfi, A.J., 2011. Deep plant-derived carbon storage in Amazonian podzols. Biogeosciences 8, 113-120.

Moore, T., Dalva, M., 2001. Some controls on the release of dissolved organic carbon by plant tissues and soils. Soil Sci. 166, 38-47.

Nealson, K.H., Myers, C.R., 1992. Microbial reduction of manganese and iron: new approaches to carbon cycling. Appl. Environ. Microbiol. 58, 439.

Nealson, K.H., Saffarini, D., 1994. Iron and manganese in anaerobic respiration: environmental significance, physiology, and regulation. Annu. Rev. Microbiol. 48, 311-343.

Nevin, K.P., Lovley, D.R., 2000. Lack of production of electron-shuttling compounds or solubilization of Fe (III) during reduction of insoluble Fe (III) oxide by Geobacter metallireducens. Appl. Environ. Microbiol. 66, 2248-2251.

Newman, D.K., 2001. How bacteria respire minerals. Science 292, 1312-1313.

J.D., R., 1982. In: Page, J.R., Miller, R.H., Keeney, D.H., Baker, D.E., Roscoe, J.R. (Eds.), Methods of Soil Analysis: Part 2, Chemical and Microbiological Properties, 2nd edn. (Madison, WI).

Pédrot, M., Le Boudec, A., Davranche, M., Dia, A., Henin, O., 2011. How does organic matter constrain the nature, size and availability of Fe nanoparticles for biological reduction? J. Colloid Interface Sci. 359, 75-85.

Poggenburg, C., Mikutta, R., Sander, M., Schippers, A., Marchanka, A., Dohrmann, R., Guggenberger, G., 2016. Microbial reduction of ferrihydrite-organic matter coprecipitates by Shewanella putrefaciens and Geobacter metallireducens in comparison to mediated electrochemical reduction. Chem. Geol. 447, 133-147.

Poggenburg, C., Mikutta, R., Schippers, A., Dohrmann, R., Guggenberger, G., 2018 Impact of natural organic matter coatings on the microbial reduction of iron oxides. Geochim. Cosmochim. Acta 224, 223-248.

Poulton, S.W., Canfield, D.E., 2005. Development of a sequential extraction procedure for iron: implications for iron partitioning in continentally derived particulates. Chem.
Geol. 214, 209-221.

R Development Core Team, 2017. R: A language and environment for statistical computing. R Foundation for Statistical Computing, Vienna.

Roden, E.E., Kappler, A., Bauer, I., Jiang, J., Paul, A., Stoesser, R., Konishi, H., Xu, H. 2010. Extracellular electron transfer through microbial reduction of solid-phase humic substances. Nat. Geosci. 3, 417-421.

Röling, W.F., Van Breukelen, B.M., Bruggeman, F.J., Westerhoff, H.V., 2007. Ecological control analysis: being (s) in control of mass flux and metabolite concentrations in anaerobic degradation processes. Environ. Microbiol. 9, 500-511.

Rouiller, J., Burtin, G., Souchier, B., 1972. La dispersion des sols dans l'analyse granulométrique. Méthode utilisant les résines échangeuses d'ions. Bull. l'ENSAIA Nancy 14, 194-205.

Royer, R.A., Burgos, W.D., Fisher, A.S., Unz, R.F., Dempsey, B.A., 2002. Enhancement of biological reduction of hematite by electron shuttling and Fe (II) complexation. Environ. Sci. Technol. 36, 1939-1946.

Sauer, D., Sponagel, H., Sommer, M., Giani, L., Jahn, R., Stahr, K., 2007. Podzol: soil of the year 2007. A review on its genesis, occurrence, and functions. J. Plant Nutr. Soil Sci. 170, 581-597.

Schädler, S., Burkhardt, C., Kappler, A., 2008. Evaluation of electron microscopic sample preparation methods and imaging techniques for characterization of cell-mineral aggregates. Geomicrobiol J. 25, 228-239.

Schmidt, M.W., Knicker, H., Kogel-Knabner, I., 2000. Organic matter accumulating in Aeh and $\mathrm{Bh}$ horizons of a podzol-chemical characterization in primary organo-mineral associations. Org. Geochem. 31, 727-734.

Schulze, K., Borken, W., Muhr, J., Matzner, E., 2009. Stock, turnover time and accumulation of organic matter in bulk and density fractions of a podzol soil. Eur. J. Soil Sci. $60,567-577$.

Shimizu, M., Zhou, J., Schröder, C., Obst, M., Kappler, A., Borch, T., 2013. Dissimilatory reduction and transformation of ferrihydrite-humic acid coprecipitates. Environ. Sci. Technol, 47, 13375-13384.

Singleton, G.A., Lavkulich, M., 1987. A soil chronosequence on beach sands, Vancouver Island, British Columbia. Can. J. Soil Sci. 67, 795-810.

Siregar, A., Kleber, M., Mikutta, R., Jahn, R., 2005. Sodium hypochlorite oxidation reduces soil organic matter concentrations without affecting inorganic soil constituents. Eur. J. Soil Sci. 56, 481-490.

Taillefert, M., Beckler, J.S., Carey, E., Burns, J.L., Fennessey, C.M., Dichristina, T.J., 2007. Shewanella putrefaciens produces an Fe(III)-solubilizing organic ligand during anaerobic respiration on insoluble Fe(III) oxides. J. Inorg. Biochem. 101, 1760-1767.

Thompson, A., 2016. The Role of Redox Variability in Structuring Iron Cycling in Soils. 2016 Goldschmidt, Japan.

Thompson, A., Chadwick, O.A., Rancourt, D.G., Chorover, J., 2006. Iron-oxide crystallinity increases during soil redox oscillations. Geochim. Cosmochim. Acta 70, 1710-1727.

Torn, M., Swanston, C., Castanha, C., Trumbore, S., 2009. Storage and Turnover of Organic Matter in Soil. Biophysico-chemical Processes Involving Natural Nonliving Organic Matter in Environmental Systems. Wiley, Hoboken, pp. 219-272.

Vermeire, M.-L., Cornu, S., Fekiacova, Z., Detienne, M., Delvaux, B., Cornélis, J.-T., 2016. Rare earth elements dynamics along pedogenesis in a chronosequence of podzolic soils. Chem. Geol. 446, 163-174.

Vermeire, M.-L., Cornélis, J.-T., Van Ranst, E., Bonneville, S., Doetterl, S., Delvaux, B., 2018. Soil microbial populations shift as processes protecting organic matter change during podzolization. Front. Environ. Sci. 6.

Viollier, E., Inglett, P., Hunter, K., Roychoudhury, A., Van Cappellen, P., 2000. The ferrozine method revisited: Fe (II)/Fe (III) determination in natural waters. Appl. Geochem. 15, 785-790.

Vodyanitskii, Y.N., Vasil'ev, A., Kozheva, A., Sataev, E., 2006. Specific features of iron behavior in soddy-podzolic and alluvial gleyed soils of the Middle Cis-Urals region. Eurasian Soil Sci. 39, 354-366.

Von Lützow, M., Kögel-Knabner, I., Ekschmitt, K., Matzner, E., Guggenberger, G., Marschner, B., Flessa, H., 2006. Stabilization of organic matter in temperate soils: mechanisms and their relevance under different soil conditions - a review. Eur. J. Soil Sci. 57, 426-455.

Von Lützow, M., Kögel-Knabner, I., Ekschmitt, K., Flessa, H., Guggenberger, G., Matzner, E., Marschner, B., 2007. SOM fractionation methods: relevance to functional pools and to stabilization mechanisms. Soil Biol. Biochem. 39, 2183-2207.

Wang, H., Zhu, J., Fu, Q.-L., Xiong, J.-W., Hong, C., Hu, H.-Q., Violante, A., 2015. Adsorption of phosphate onto ferrihydrite and ferrihydrite-humic acid complexes. Pedosphere 25, 405-414.

Weber, K.A., Achenbach, L.A., Coates, J.D., 2006. Microorganisms pumping iron: anaerobic microbial iron oxidation and reduction. Nat. Rev. Microbiol. 4, 752-764.

Zachara, J.M., Fredrickson, J.K., Smith, S.C., Gassman, P.L., 2001. Solubilization of Fe (III) oxide-bound trace metals by a dissimilatory Fe (III) reducing bacterium. Geochim. Cosmochim. Acta 65, 75-93.

Zachara, J.M., Kukkadapu, R.K., Fredrickson, J.K., Gorby, Y.A., Smith, S.C., 2002 Biomineralization of poorly crystalline Fe(III) oxides by dissimilatory metal reducing bacteria (DMRB). Geomicrobiol J. 19, 179-207. 